\title{
Properties and classification of heavily eroded post-chernozem soils in Proszowice Plateau (southern Poland)
}

\begin{abstract}
The morphology and properties of heavily eroded soils found in chernozems in the upland landscape of the Proszowice Plateau (southern part of Poland) was presented. The issue of classification of these soils was also discussed. Taking into account the terrain context, it should have been assumed that these soils were formed as a result of strong erosion (truncation) of chernozems. These (post-chernozem) soils were relatively young, in which only the development of humus horizon can be documented. However, the accumulation of humus was hampered by constantly intense erosion processes. Evidence of the occurrence of the illuviation process as well as formation of cambic horizon is not visible macroscopically and microscopically. These soils are often classified as weakly developed soils though despite the poor development of the soil profile, they are characterized by potentially high productivity, which results both from the properties of their parent material (texture, porosity) and from their youthfulness (carbonate content both in fine earths and in nodules, high $\mathrm{pH}$ in whole profile). Therefore, the name proposed in Polish Soil Classification, 6th edition ('pararędzina') seems to be justified. These soils would be classified as Entisols according to USDA Soil Taxonomy and as Regosols according to WRB.
\end{abstract}

Keywords: Chernozems, Mollisols, Regosols, Entisols, pararędzina, soil erosion, soil classification

\section{INTRODUCTION}

The erosion of the uppermost part of each soil (topsoil) leads to limiting all its functions (Kaiser 2004) because the most productive part of soil containing humus and having the best developed pedogenic structure, was removed (Izaurralde et al. 2006). This phenomenon occurs everywhere on the planet but it is particularly important in arable areas, where humans cause a strong intensification of natural erosion processes (eg. Phillips et al. 1999; Jankauskas and Fullen 2002; Dotterweich et al. 2013, Podlasiński 2013; Kobierski 2013; Świtoniak et al. 2016). Soil erosion has become a global problem (Montanarella et al. 2015). According to various sources it may be estimated that 75 billion tons $(\mathrm{Pg})$ of soil is eroded annually from arable land all over the world and a significant increase in the rate of soil erosion is observed in some regions of the world: South America (predicted average soil erosion $3.53 \mathrm{Mg} \mathrm{ha}^{-1}$ year, Africa (3.51 Mg ha ${ }^{-1}$ year $\left.^{-1}\right)$ and Asia (3.47 $\mathrm{Mg} \mathrm{ha}^{-1}$ year $^{-1}$ ) (Borrelli et al. 2017).

Current rate of soil erosion growth in Europe is not very high. This includes Poland, which is among the countries with a relatively optimistic forecast of change (Borrelli et al., 2017). However, it can be estimated that about $29 \%$ of the area of Poland (including $21 \%$ of arable land and $8 \%$ of forest area) is threatened by water erosion, and the risk of strong erosion concerns about $4 \%$ of Poland (Józefaciuk et al. 2014). Among the most endangered are the mountains, where agriculture nowadays ceases to be the dominant mode of land use and loess upland areas where farming is still very intense (Józefaciuk et al. 2014). A large transformation of soils due to erosion is observed in loess areas, which is a result of soil texture, relief conditions and long-term use (Gąsior and Partyka 1999; Licznar and Drozd 1985; Klimowicz and Uziak 2001; Paluszek 2013; Żyła 2009). Soil erosion processes transformed most of the chernozems occurring in loess uplands of Poland (Dobrzański 1962; Klimowicz and Uziak 2001).

The aim of this work was to analyse the morphology and properties of heavily eroded chernozems found in the Proszowice Plateau (southern part of Poland). The issue of classification of these soils was also discussed.

\section{MATERIAL AND METHODS}

\section{Study area}

The research was carried out on the Proszowice Plateau, where chernozems originally developed (Olszewski et al. 1965; Komornicki 1974). Several latitudinal flattening ridges covered with aeolian 
sediments (late Vistulian loess) occur here (Walczowski 1982, 1984; Jersak 1973). In most cases wide flattening uplands pass through gentle convex-concave slope into the valleys (Michno 2004). The mean annual air temperature in the study area is approximately $7-8^{\circ} \mathrm{C}$ and mean annual precipitation is $540 \mathrm{~mm}$.
Agricultural activity on the Proszowice Plateau was already initiated in Neolithic Age (Kruk et al. 1996; Valde-Nowak 2004). Continuous farming was carried out since the Middle Ages in this part of Poland (Michno 2004). As a result of denudation a network of slope terraces and gullies was created locally.

TABLE 1. Morphology (selected features) of highly eroded post-chernozem soils against the background of the non-truncaded chernozem (profile: Witów 4)

\begin{tabular}{|c|c|c|c|c|c|c|c|}
\hline \multirow[t]{2}{*}{ Horizon } & \multirow[t]{2}{*}{ Depth (cm) } & \multirow[t]{2}{*}{ Colour (moist) } & \multirow[t]{2}{*}{ Colour (dry) } & \multicolumn{4}{|c|}{ Secondary carbonates precipitations } \\
\hline & & & & Nodules & Rhizoliths & $\begin{array}{l}\text { Pseudo- } \\
\text { mycelium }\end{array}$ & Other \\
\hline \multicolumn{8}{|c|}{ Boronice 1} \\
\hline Akcp & $0-23$ & 10YR 5/3 & 10YR 7/2 & + & + & - & +++ \\
\hline Ckc & $23-50$ & 10YR 6/4 & $2.5 \mathrm{Y} 8 / 3$ & + & +++ & ++ & +++ \\
\hline Ckcg1 & $50-90$ & 10YR 5/4 & $2.5 \mathrm{Y} 8 / 3$ & ++ & +++ & - & +++ \\
\hline Ckcg2 & $90-150+$ & 10YR 5/4 & $2.5 \mathrm{Y} 8 / 3$ & ++ & +++ & - & ++ \\
\hline \multicolumn{8}{|c|}{ Boronice 2} \\
\hline Ap & $0-25$ & 10YR 5/4 & $10 \mathrm{YR} 7 / 3$ & - & - & - & - \\
\hline Ckc1 & $25-39$ & 10YR 6/4 & 10YR 7/4 & + & + & - & + \\
\hline $\mathrm{Ckc} 2$ & 39-90 & 10YR 6/4 & $10 \mathrm{YR} 7 / 3$ & ++ & +++ & - & ++ \\
\hline Ckcg1 & $90-130$ & $2.5 \mathrm{Y} 6 / 4$ & $2.5 \mathrm{Y} 7 / 3$ & ++ & ++ & - & + \\
\hline Ckcg2 & $130-150+$ & 10 YR $5 / 3$ & $10 \mathrm{YR} 7 / 2$ & +++ & +++ & - & + \\
\hline \multicolumn{8}{|c|}{ Słonowice 5} \\
\hline Akcp & $0-25$ & 10YR 4/3 & $10 \mathrm{YR} 6 / 3$ & + & + & - & ++ \\
\hline $\mathrm{Ckc}$ & $25-55$ & 10YR 6/4 & 10 YR $8 / 3$ & ++ & +++ & + & +++ \\
\hline Ckcg1 & $55-90$ & 10YR 6/4 & $10 \mathrm{YR} 8 / 3$ & ++ & +++ & - & +++ \\
\hline Ckcg2 & $90-150+$ & 10YR 5/4 & $10 \mathrm{YR} 8 / 3$ & ++ & +++ & - & +++ \\
\hline \multicolumn{8}{|c|}{ Słonowice 7} \\
\hline Akp & $0-25$ & $2.5 Y 5 / 3$ & $2.5 \mathrm{Y} 6 / 3$ & - & + & - & ++ \\
\hline Ckc1 & $25-35$ & 10YR 6/4 & $2.6 Y 8 / 3$ & + & ++ & - & ++ \\
\hline Ckc2 & $35-70$ & 10YR 6/4 & $2.5 \mathrm{Y} 8 / 3$ & + & +++ & - & +++ \\
\hline Ckcg & $70-150+$ & 10YR 6/4 & $10 \mathrm{YR} 8 / 2$ & +++ & +++ & - & ++ \\
\hline \multicolumn{8}{|c|}{ Wymysłów 1} \\
\hline Akp & $0-20$ & 10YR 5/3 & $2.5 \mathrm{Y} 6 / 3$ & - & - & - & + \\
\hline Ckc & $20-45$ & 10YR 6/4 & $10 \mathrm{YR} 8 / 3$ & + & +++ & - & +++ \\
\hline Ckcg1 & $45-80$ & 10YR 6/4 & $2.5 \mathrm{Y} 8 / 3$ & ++ & +++ & - & +++ \\
\hline Ckcg2 & $80-150+$ & 10YR 6/4 & $10 \mathrm{YR} 8 / 3$ & ++ & +++ & - & +++ \\
\hline \multicolumn{8}{|c|}{ Wymysłów 2} \\
\hline Akcp & $0-25$ & $2.5 Y 5 / 4$ & $2.5 \mathrm{Y} 7 / 3$ & + & ++ & - & ++ \\
\hline $\mathrm{Ckc}$ & $25-55$ & $2.5 \mathrm{Y} 6 / 4$ & $2.5 \mathrm{Y} 7 / 3$ & ++ & +++ & - & +++ \\
\hline Ckcg & $55-150+$ & $2.5 \mathrm{Y} 6 / 4$ & $2.5 \mathrm{Y} 8 / 3$ & ++ & +++ & - & ++ \\
\hline \multicolumn{8}{|l|}{ Witów 4} \\
\hline Ap & $0-28$ & 10YR 3/1 & $10 \mathrm{YR} 5 / 2$ & - & - & - & - \\
\hline $\mathrm{A}$ & $28-45$ & 10YR 2/1 & 10YR 4/1 & - & - & - & - \\
\hline $\mathrm{A} / \mathrm{C} 1$ & $45-60$ & 10YR 3/1 & 10YR 4/1 & - & - & - & - \\
\hline $\mathrm{A} / \mathrm{C} 2$ & $60-82$ & 10 YR 5/3 & $10 \mathrm{YR} 7 / 3$ & - & - & + & + \\
\hline $\mathrm{Ck}$ & $82-92$ & 10YR 5/3 & 10YR 7/4 & - & + & - & +++ \\
\hline Ckcg & $92-160+$ & $2.5 \mathrm{Y} 6 / 4$ & $2.5 \mathrm{Y} 8 / 3$ & ++ & +++ & - & +++ \\
\hline
\end{tabular}


Significant slope areas were also eroded, especially the upper (convex) slope sections. A thick deluvium/ colluvium covers at the footslope as well as in the bottoms of the valleys was developed (Michno 2004).

\section{Field works and laboratory analysis}

During field works (in arable lands under intensive farming, conducted after harvesting), representative research plots on the most eroded sections of the slopes were selected. Morphology of soil (profile located in the central part of investigated plot) was described and sampled to the $150 \mathrm{~cm}$ depth. A reference soil representing non-truncated chernozem was also described and sampled in close proximity. A total of 12 truncated post-chernozem soils and 5 non-truncated chernozems were tested and some profiles have been selected for this paper (Table 1, 2). Profiles Słonowice 1 and Słonowice (see: figure $2 \mathrm{~A}$ and $2 \mathrm{~B}$ captions) have the same properties as other truncated chernozems presented (Table 1).

In laboratory, after drying, bulk soil samples were crushed with a soft tool and then sieved through a $2 \mathrm{~mm}$ sieve. Next, the following parameters were determined: particle size distribution (texture), the content of soil organic carbon (SOC) by the Tiurin method (in triplicate), content of carbonates using Scheibler method (as an equivalent of $\mathrm{CaCO}_{3}$, in triplicate) and bulk density using core method (100 $\mathrm{cm}^{3}$, in triplicate). The SOC stock was calculated (Wasak and Drewnik 2015). Undisturbed soil samples after drying at $40^{\circ} \mathrm{C}$ were impregnated with araldite resin. Micromorphological analyses were performed on $25-30 \mu \mathrm{m}$ thin sections using a polarizing microscope.

\section{RESULTS}

The reference non-truncated chernozem (Witów 4) had general soil profile morphology: A-A/C-Ck(c, g) (Table 1, Figure 1A). Below humus horizons $(\mathrm{Ap}+\mathrm{A})$, a set of transition $\mathrm{A} / \mathrm{C}$ horizons were present (gradual transition) and then parent material ( $\mathrm{Ck}+\mathrm{Ckcg})$ could be found. In contrast, investigated heavily eroded soils had simple soil profile morphology: Akcp(kp,p)$\mathrm{Ckc}(\mathrm{g})$ (Table 1, Figure 1B).

Humus horizon in heavily eroded soils had a dull yellowish brown moist colour 10YR 4-5/3-4 (10YR 6-7/2-3 dry) and its thickness corresponded to the depth of ploughing (it is $\sim 20-25 \mathrm{~cm}$ ) (Table 1).
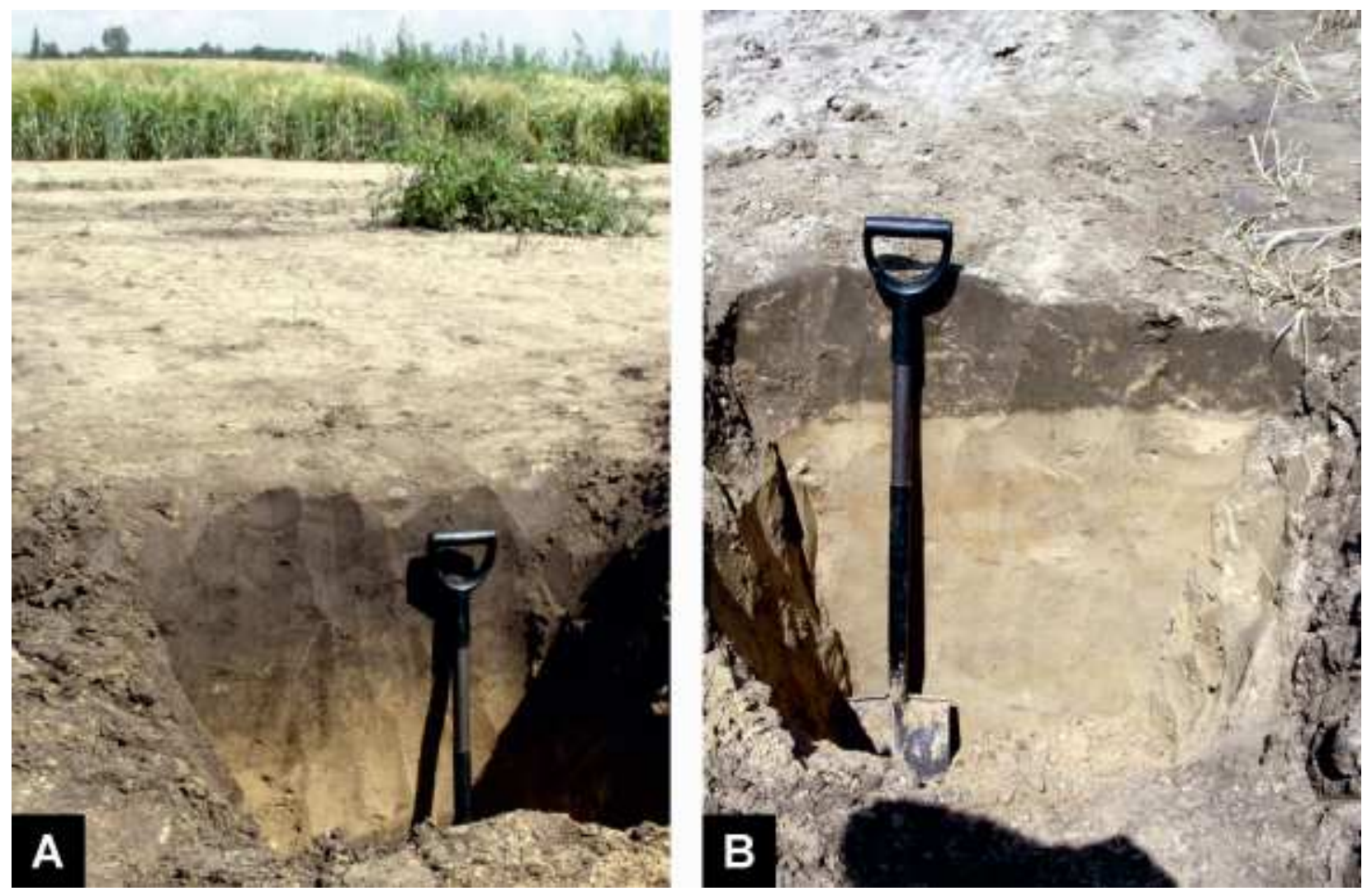

FIGURE 1. Non-truncated chernozem (A) and heavily eroded (truncated) post-chernozem soil (B) in Proszowice Plateau landscape (Słonowice) 

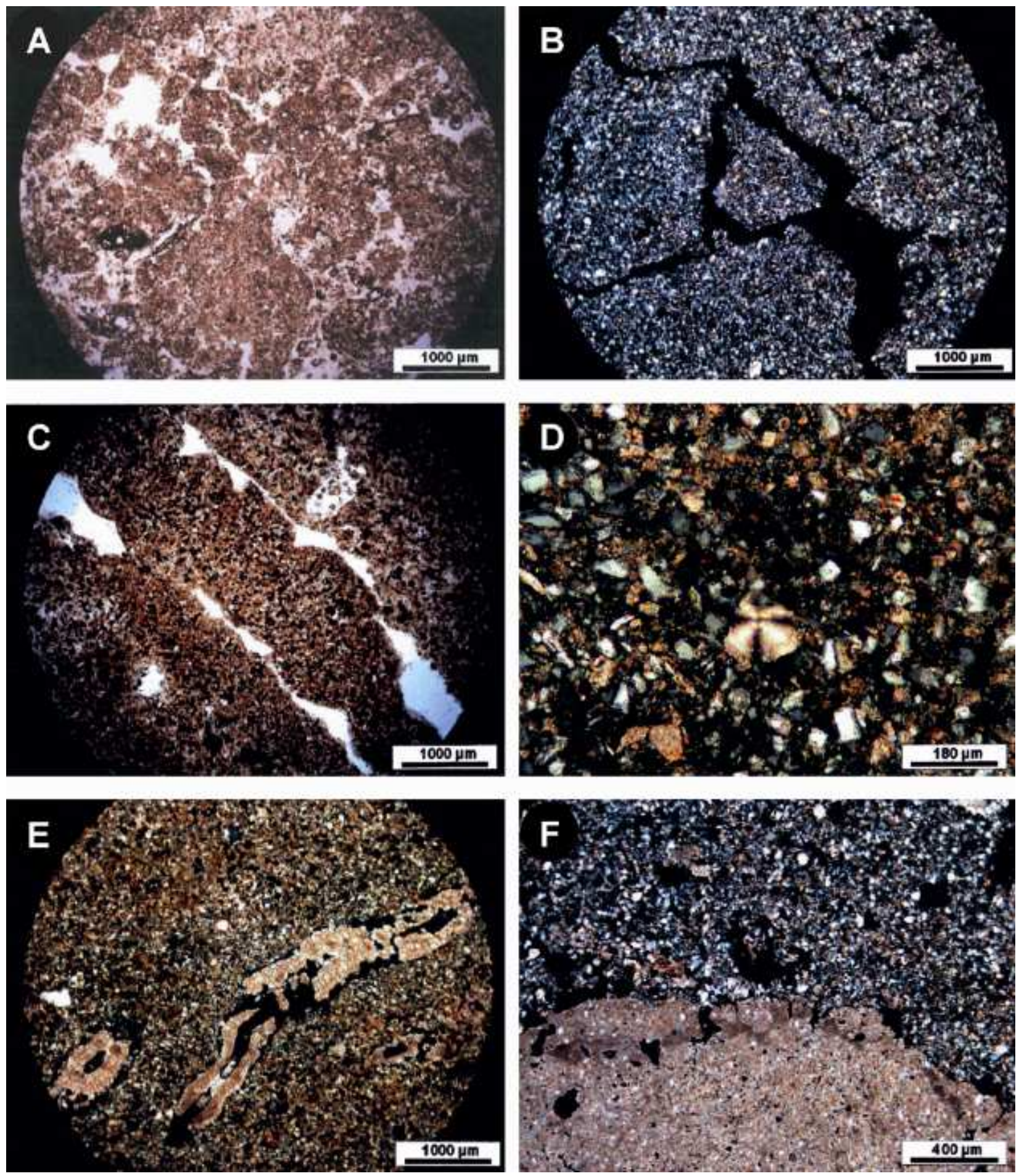

FIGURE 2. Micromorphological features of investigated soils: A - subangular microstructure in humus horizon Ap, non-truncated chernozem, Słonowice 1, PPL; B - angular microstructure in humus horizon Akcp, post-chernozem soil, Słonowice 2, XPL; C coprolite aggregates in channel in humus horizon Akp, post-chernozem soil, Słonowice 2, PPL; D - calcite crystal micromass in parent material C, post-chernozem soil, Słonowice 5, XPL; E - rhyzolites in parent material Ckc, post-chernozem soil, Boronice 1, XPL; F - contact of calcareous nodule with typical loess in parent material Ckcg, non-truncated chernozem, Witów 4, XPL 
In heavily eroded soils dull yellow fragments of pure loess in humus horizon mass could be found (Figure 1B). Under the humus-ploughing horizon $\mathrm{A}(\mathrm{k}, \mathrm{kc}) \mathrm{p}$ the parent material C (loess) was directly present in these soils. The transition between humus horizon and parent material was very abrupt. Traces of humus illuviation had not been found (Figure 1B). White secondary precipitation of carbonates could be found in the whole soil profile (including uppermost humus horizon = topsoil), mainly in the form of nodules and rhyzolites (Table 1). The content of secondary carbonates (precipitations) was clearly lower in humus horizon A compared to parent material C. In relation to the reference soil, i.e. non-truncated chernozem

TABLE 2. Basic properties of of highly eroded post-chernozem soils against the background of the non-truncaded chernozem (profile: Witów 4)

\begin{tabular}{|c|c|c|c|c|c|c|c|c|c|}
\hline \multirow[t]{2}{*}{ Horizon } & \multirow{2}{*}{$\begin{array}{l}\text { Depth } \\
(\mathrm{cm})\end{array}$} & \multicolumn{3}{|c|}{ Content (\%) in fine fraction } & \multirow{2}{*}{$\begin{array}{l}\text { Bulk } \\
\text { - Density } \\
\left(\mathrm{Mg} / \mathrm{m}^{3}\right)\end{array}$} & \multirow{2}{*}{$\begin{array}{l}\mathrm{pH} \\
\text { (in water) }\end{array}$} & \multirow{2}{*}{$\begin{array}{l}\text { Equivalent } \\
\text { of } \mathrm{CaCO}_{3} \\
(\%)\end{array}$} & \multirow{2}{*}{$\begin{array}{l}\text { Organic } \\
\text { Carbon } \\
(\%)\end{array}$} & \multirow{2}{*}{$\begin{array}{l}\text { OC stock } \\
(0-150 \mathrm{~cm}) \\
(\mathrm{Mg} / \mathrm{ha})\end{array}$} \\
\hline & & Sand & Silt & Clay & & & & & \\
\hline \multicolumn{10}{|c|}{ Boronice 1} \\
\hline Akcp & $0-23$ & 14 & 69 & 17 & 1.46 & 7.87 & 10.40 & 0.66 & 50.3 \\
\hline Ckc & $23-50$ & 12 & 73 & 15 & 1.44 & 8.18 & 13.83 & 0.19 & \\
\hline Ckcg1 & $50-90$ & 16 & 69 & 15 & 1.45 & 8.17 & 13.24 & 0.16 & \\
\hline Ckcg2 & $90-150+$ & 14 & 71 & 15 & 1.47 & 8.19 & 9.94 & 0.13 & \\
\hline \multicolumn{10}{|c|}{ Boronice 2} \\
\hline Ap & $0-25$ & 11 & 66 & 23 & 1.21 & 6.92 & 0.44 & 0.63 & 51.3 \\
\hline Ckc1 & $25-39$ & 10 & 72 & 18 & 1.49 & 7.70 & 1.91 & 0.16 & \\
\hline $\mathrm{Ckc} 2$ & 39-90 & 14 & 65 & 21 & 1.46 & 7.83 & 6.52 & 0.15 & \\
\hline Ckcg1 & $90-130$ & 13 & 65 & 22 & 1.46 & 7.77 & 3.17 & 0.18 & \\
\hline Ckcg2 & $130-150$ & 21 & 66 & 13 & 1.66 & 7.89 & 4.60 & 0.22 & \\
\hline \multicolumn{10}{|c|}{ Słonowice 5} \\
\hline Akcp & $0-25$ & 14 & 74 & 12 & 1.40 & 7.92 & 7.06 & 0.63 & 49.1 \\
\hline $\mathrm{Ckc}$ & $25-55$ & 14 & 75 & 11 & 1.47 & 8.23 & 12.18 & 0.16 & \\
\hline$\overline{C k c g 1}$ & $55-90$ & 14 & 73 & 13 & 1.45 & 8.24 & 11.15 & 0.16 & \\
\hline Ckcg2 & $90-150+$ & 12 & 76 & 12 & 1.45 & 8.18 & 9.76 & 0.14 & \\
\hline \multicolumn{10}{|c|}{ Słonowice 7} \\
\hline Akp & $0-25$ & 14 & 72 & 14 & 1.38 & 7.86 & 6.87 & 0.65 & 39.4 \\
\hline Ckc1 & $25-35$ & 13 & 72 & 15 & 1.46 & 8.19 & 8.74 & 0.15 & \\
\hline Ckc2 & $35-70$ & 12 & 73 & 15 & 1.45 & 8.23 & 12.08 & 0.10 & \\
\hline Ckcg & $70-150+$ & 12 & 74 & 14 & 1.51 & 8.24 & 8.38 & 0.08 & \\
\hline \multicolumn{10}{|c|}{ Wymysłów 1} \\
\hline Akp & $0-20$ & 19 & 64 & 17 & 1.25 & 7.60 & 3.70 & 0.65 & 43.9 \\
\hline $\mathrm{Ckc}$ & $20-45$ & 19 & 60 & 15 & 1.41 & 7.97 & 13.92 & 0.26 & \\
\hline Ckcg1 & $45-80$ & 18 & 66 & 12 & 1.56 & 7.97 & 13.12 & 0.11 & \\
\hline Ckcg2 & $80-150+$ & 17 & 64 & 13 & 1.49 & 7.95 & 11.25 & 0.12 & \\
\hline \multicolumn{10}{|c|}{ Wymysłów 2} \\
\hline Akcp & $0-25$ & 18 & 67 & 15 & 1.35 & 7.66 & 9.94 & 0.57 & 46.5 \\
\hline $\mathrm{Ckc}$ & $25-55$ & 20 & 68 & 12 & 1.56 & 8.05 & 10.86 & 0.12 & \\
\hline Ckcg & $55-150+$ & 16 & 71 & 13 & 1.52 & 8.09 & 9.79 & 0.15 & \\
\hline \multicolumn{10}{|l|}{ Witów 4} \\
\hline Ap & $0-28$ & 16 & 65 & 19 & 1.29 & 5.07 & - & 1.15 & 104.1 \\
\hline $\mathrm{A}$ & $28-45$ & 14 & 66 & 20 & 1.37 & 6.00 & - & 1.35 & \\
\hline $\mathrm{A} / \mathrm{C} 1$ & $45-60$ & 13 & 66 & 21 & 1.34 & 6.71 & - & 0.68 & \\
\hline $\mathrm{A} / \mathrm{C} 2$ & $60-82$ & 14 & 68 & 18 & 1.32 & 7.17 & 0.08 & 0.35 & \\
\hline $\mathrm{Ck}$ & $82-92$ & 14 & 69 & 17 & 1.32 & 7.42 & 0.20 & 0.22 & \\
\hline Ckcg & $92-160+$ & 14 & 69 & 17 & 1.48 & 8.06 & 9.60 & 0.05 & \\
\hline
\end{tabular}


(Table 1: Witów 4 profile), the studied soils were clearly shallower and have lighter (value higher by 2-3 units) humus horizon, there is no transition $\mathrm{A} / \mathrm{C}$ horizon and secondary carbonates occur starting from topsoil.

Micromorphological analysis had shown that in the humus horizon in heavily eroded soil, the angular microstructure could be found (Figure 2B), which clearly distinguished these soils from reference nontruncated chernozem, where the soil microstructure in the humus horizon was much better developed and dominated by granular, crumby and subangular structure (Figure 2A). However in heavily eroded soils, clear traces of earthworm activity could be found (Figure 2C). In a deeper part of the soil, the micromorphological view of both the non-truncated chernozem and the heavily eroded soils were dominated by the features associated with the presence of primary carbonates (Figure 2D), secondary carbonates (Fig. $2 \mathrm{E}, \mathrm{F})$ and the presence of mineral particles typical for loess (Fig. 2D, E, F).

All analysed soils had a texture reflecting the properties of the soil's parent material. There are no stones and gravel (excluding nodules), and silt fraction $(0.05-0.002 \mathrm{~mm})$ predominated in the fine parts $(60-76 \%)$. The share of clay fraction $(<0.002$ $\mathrm{mm})$ and sand fraction $(2-0.05 \mathrm{~mm})$ was smaller (11-23\% and $10-20 \%$ respectively) (Table 2). The increase in the clay fraction content along the depth typical for illuviation process was not found both in eroded soils and in the reference soil. Similarly, the bulk density was uniform in all soils, ranging from 1.21 to $1.56 \mathrm{Mg} \mathrm{m}^{-3}$. In most cases (with the exception of the Boronice 2 and Wymysłów 1 profiles), the clearly higher value of the bulk density in the topsoil of eroded soils compared to the topsoil of reference soil could be noticed.

The eroded soils generally had an alkaline reaction starting in topsoil ( $\mathrm{pHw}$ 7.6-8.2) (Table 2). The exception was the profile of Boronice 2, where the $\mathrm{pHw}$ was 6.9 in A horizon. Reaction clearly distinguished heavily eroded soils from the reference non-truncated chernozem (Witów 4), where acidic and slightly acidic reaction was determined in humus horizons $(\mathrm{pHw}$ 5.0-6.0), neutral reaction in transition horizons ( $\mathrm{pHw}$ 6.7-7.2), and which was alkaline ( $\mathrm{pHw} 7.4-8.1$ ) only in the parental material reaction.

All of the heavily eroded soils had very uniform content of SOC in the humus horizons $(0.57-0.66 \%)$, which also distinguished them from the reference nontruncated chernozem, where the SOC content in the humus horizon was $1.15-1.35 \%$, and which was $0.35-$ $0.68 \%$ (Table 2) in transition horizons (absent in eroded soils). Finally, it turned out that the SOC stock of the whole soil profile $(0-150 \mathrm{~cm})$ in heavily eroded soils was half as high as in the reference chernozem ( $40-50 \mathrm{Mg} \mathrm{ha}^{-1}$ vs. ( $100 \mathrm{Mg} \mathrm{ha}^{-1}$ respectively) (Table 2). The carbonate content (equivalent) was the third element that distinguished heavily eroded soils from the reference soil. In heavily eroded soil, carbonates were usually found in large quantities (exceeding even $10 \%$ ) starting in the topsoil, whereas in non-truncated chernozems carbonates of this kind content occurred only at a depth of over $90 \mathrm{~cm}$ (Table 2).

\section{DISCUSSION}

The heavily eroded soils found among the chernozems in the upland landscape of the Proszowice Plateau were characterized by properties indicating their relatively simple genesis. Their morphology and properties clearly proved that the most important process was the erosion (denudation) of the original chernozems by at least $60 \mathrm{~cm}$, which was indirectly indicated as difference in the thickness of humus horizons in truncated (heavily eroded) and non-truncated soils. This could correspond with intensive erosion related to agricultural activity, as it was found in a similar area (near Hrubieszów in Poland), also on chernozems: in 30 years the thickness of the eroded soil was on average $62 \mathrm{~cm}$ (Józefaciuk and Józefaciuk 1984). It is worth emphasizing that these changes significantly reduced carbon stocks, which is typical for eroded chernozems (e.g. Wiesmeier et al. 2015), while, in contrast, the truncation of Luvisols in northern Poland didn't lead to a significant reduction in carbon stocks because previously content of humus in non-eroded A horizon was relatively low (Świtoniak et al. 2015).

The manifestations of the illuviation processes as well as formation of cambic horizon in some chernozems of Proszowice Plateau were previously documented (Żyła 2007). However, in soils presented in this work, such traces were not found either in macroscopic or in microscopic analysis. This might have indicated the continuous duration of the erosion. The second proof of the relative youthfulness of the studied soils was that carbonates could be found starting from topsoil, which was associated with a very high soil $\mathrm{pH}$ in the entire profile. It could be interpreted that there was not enough time to leach out carbonates even from the near surface part of the soil profile. The third proof of the youthfulness of these soils was that the angular microstructure occurred in the humus horizon, which was not typical for biogenically active chernozems (however worm activity was documented). Important evidence for the transformation of soil structure (structure type and stability of soil aggregates) was 
provided by Paluszek (1995) in research conducted on similar soils in the Lublin Upland (East Poland). The fourth proof respectively was a relatively low and very uniform concentration of humus $(\sim 0.6 \%)$ in topsoil. Finally heavily eroded soils in Proszowice Plateau were most probably still under extensive erosion, as simply indicated by the terrain context.

The highly eroded soils found among the chernozems in the upland landscape of the Proszowice Plateau had surprisingly unified morphology and properties, which most probably resulted from their genesis and homogeneity of the parent material. Their taxonomic affiliation in each of the applied classification systems showed their uniformity (Table 3 ). The over-high colour value did not allow us to determine the mollic/mollik diagnostic horizon in these soils in each of referenced classification systems (Table 3). According to Polish Soil Classification, 6th edition (Kabała et al. 2019; Systematyka gleb Polski, 2019) the thickness of humus (resulting from the ploughing depth, $\sim 20-25 \mathrm{~cm}$ ) also did not allow the designate of mollik diagnostic horizon. Erosional degradation of humus horizons and consequently, a strong lightening of their colour due to erosion in loess areas was also reported by Novák et al. (2018) and Žížala et al. (2019). Therefore the described heavily eroded soils (Table 3) could not be classified as Mollisols/Chernozems/chernozems. There was a lot of secondary carbonates (in various forms) in these soils, however, the total carbonate content also did not allow us to designate 'kalcik' diagnostic horizon according to Polish Soil Classification, 6th edition (Systematyka gleb Polski 2019), as well as 'calcic' diagnostic horizon according to USDA Soil Taxonomy (Soil Survey Staff 2014) and WRB (IUSS Working Group WRB 2015) ( $\geq 15 \%$ of eqCaCO $\mathrm{Ca}_{3}$ is required).

Two approaches to classifying such soils could be distinguished. One of the most important was the approach of soil genesis, so the soils would be classified as weakly developed post-erosive soils, e.g. according to Polish Soil Classification, 5th edition (Systematyka gleb Polski 2011) it would be 'weakly developed post-erosion soil' (Polish: 'gleba słabo ukształtowana erozyjna') (Table 3). The heavily eroded had been also classified as 'siltosols' (Żyła 2007) due to lack of adequate definition in Polish Soil Classification, 4th edition (Systematyka gleb Polski 1989). According to the second approach, the advancement of the soil formation and soil properties was predominant, e.g. these soils would be classified as Udorthents (Soil Survey Staff 2014) or as Regosols (IUSS Working Group WRB 2015). Partly according to this approach, such soils were classified as 'pararendzinas' (Polish: 'pararędziny') according to Polish Soil Classification, 6th edition (Kabała et al. 2019; Systematyka gleb Polski 2019). This is allowed according to this classification, because both in the fine earth and in nodules carbonates are found (Tables 1, 2, Figure 2F) in the depth $30-60 \mathrm{~cm}$. The nodule can be equated with gravel or stones with a calcium cement (see: Figure 2F). This seemed to be an appropriate solution, because it reflected both the weak advancement of soil-forming processes and a high carbonate content (both: primary and secondary) starting in topsoil. Finally, it should be pointed out that in the past the heavily eroded chernozems in Poland had been classified as 'rendzinas' and 'pararendzinas' (Polish: "rędziny" and "pararędziny") by Borowiec $(1966,1967)$.

\section{CONCLUSIONS}

The morphology and properties of heavily eroded soils found among chernozems in the upland landscape of the Proszowice Plateau were very similar. Taking into account the terrain context, it should have been assumed that these soils were formed as a result of strong erosion (denudation) of chernozems. These were relatively young soils, in which only the development of humus horizon can be documented. However, the accumulation of humus was hampered by constantly intense erosion processes. Evidence of the occurrence of the illuviation process as well as formation of cambic horizon is not visible macroscopically and microscopically.

These soils are often classified as weakly developed soils, however, despite the poor development of the

TABLE 3. Classification of soils under study

\begin{tabular}{lllll}
\hline Soil & $\begin{array}{l}\text { Soil Taxonomy } \\
(2014)\end{array}$ & $\begin{array}{l}\text { World Reference Base } \\
\text { for Soil Resources } \\
(2014)\end{array}$ & $\begin{array}{l}\text { Systematyka Gleb Polski } \\
(2011)\end{array}$ & $\begin{array}{l}\text { Systematyka Gleb Polski } \\
(2019)\end{array}$ \\
\hline $\begin{array}{l}\text { Boronice 1, Boronice 2, } \\
\text { Słonowice 5, Słonowice }\end{array}$ & Udorthent & $\begin{array}{l}\text { Eutric Regosol } \\
\text { (Aric, Protocalcic, }\end{array}$ & Gleba słabo \\
7, Wymysłów 1, & Siltic, Ochric) & Pararędzina właś ciwa \\
Wymysłów 2 & Hapludoll & $\begin{array}{l}\text { Haplic Cherno } \\
\text { (Siltic, Aric) }\end{array}$ & Czarnoziem typowy & Czarnoziem typowy \\
\hline Witów 4 & & & \\
\hline
\end{tabular}


soil profile, they are characterized by potentially high productivity, which results both from the properties of their parent material (texture, porosity) and from their youthfulness (carbonate content and high $\mathrm{pH}$ in whole profile). Therefore, the name proposed in Polish Soil Classification, 6th edition ('pararędzina') seems to be justified.

\section{REFERENCES}

Borowiec J., 1966. Wpływ wylesienia i użytkowania rolniczego na morfologię i właściwości czarnoziemu w terenie urzeźbionym. Annales UMCS, seria E, 21: 83-103.

Borowiec J., 1967. Czarnoziemy Wyżyny Lubelskiej. Cz. II. Problemy genezy, ewolucji i typologii gleb. Annales UMCS, seria B, 22: 39-58.

Borrelli P., Robinson D.A., Fleischer L.R., Lugato E., Ballabio C., Alewell C., Meusburger K., Modugno S., Schütt B., Ferro V., Bagarello V., Van Oost K., Montanarella L., Panagos P., 2017. An assessment of the global impact of 21st century land use change on soil erosion. Nature Communications 8: 2013.

Dobrzański B., 1962. Aktualne zagadnienia i perspektywy badań nad erozją gleb. Roczniki Gleboznawcze - Soil Science Annual 11: 219 pp.

Dotterweich M., Stankoviansky M., Minár J., Koco Š., Papčo P., 2013. Human induced soil erosion and gully system development in the Late Holocene and future perspectives on landscape evolution: the Myjava Hill Land, Slovakia. Geomorphology 201: 227-245.

Gąsior J., Partyka A., 1999. Czarnoziemy południowo-wschodniej Polski i ich degradacja. Zeszyty Problemowe Postępów Nauk Rolniczych 467: 234-232.

IUSS Working Group WRB, 2015. World References Base for Soil Resources 2014, Update 2015. World Soil Resources Reports, 106, FAO, Rome: 192 pp.

Izaurralde R.C., Malhi S.S., Nyborg M., Solberg E.D., QuirogaJakas M.C., 2006. Crop performance and soil properties in two artificially eroded soils in north-central Alberta. Agronomy Journal 98(5): 1298-1311.

Jankauskas B., Fullen M.A., 2002. A pedological investigation of soil erosion severity on undulating land in Lithuania. Canadian J. Soil Sciences 82: 311-321.

Jersak J., 1973. Litologia i stratygrafia lessu wyżyn południowej Polski. Acta Geographica Lodziensia 32: 125 pp.

Józefaciuk A., Nowocień E., Wawer R., 2014. Erozja gleb w Polsce - skutki środowiskowe i gospodarcze, działania zaradcze. Monografie i Rozprawy Naukowe IUNG PIB 44: $260 \mathrm{pp}$.

Józefaciuk C., Józefaciuk A., 1984. Zmiany rzeźby terenu w Werbkowicach pod wpływem erozji w latach 1950-1980. Pamiętnik Puławski 83: 165-177.

Kabała C., Charzyński P., Chodorowski J., Drewnik M., Glina B., Greinert A., Hulisz P., Jankowski M., Jonczak J., Łabaz B., Łachacz A., Marzec M., Mendyk Ł., Musiał P., Musielok Ł., Smreczak B., Sowiński P., Świtoniak M., Uzarowicz Ł., Waroszewski J., 2019. Polish Soil Classification, 6th edition - principles, classification scheme and correlations. Soil Science Annual 70(2): 71-97.
Kaiser J., 2004. Wounding Earth's fragile skin. Science 304: 1616-1618.

Klimowicz Z., Uziak S., 2001. The influence of long-term cultivation on soil properties and patterns in an undulating terrain in Poland. Catena 43: 177-189.

Kobierski M., 2013. Morphology, properties and mineralogical composition of eroded luvisols in selected morainic areas of the Kujavian and Pomeranian Province. University of Technology and Life Sciences, Bydgoszcz.

Komornicki T., 1974. Gleby terytorium miasta Krakowa. Folia Geographica, ser. Geographica-Physica 8: 145-151.

Kruk J., Milisauskas S., Alexandrowicz S.W., Śnieszko Z., 1996. Osadnictwo i zmiany środowiska naturalnego Wyżyn Lessowych. Studium archeologiczne i paleogeograficzne nad neolitem w Dorzeczu Nidzicy. Instytut Archeologii i Etnologii PAN, Kraków: 139 pp.

Licznar M., Drozd J., 1985. Wpływ erozji na właściwości związków próchnicznych w niektórych jednostkach systematycznych gleb. Roczniki Gleboznawcze - Soil Science Annual 36(3): 189-199.

Michno A., 2004. Transformacja doliny dolnej Nidzicy w holocenie. IGiGP UJ, Kraków: 98 pp.

Montanarella L., Pennock D.J., McKenzie N.J., Badraoui M., Chude V., Baptista I., Mamo T., Yemefack M., Singh Aulakh M., Yagi K., Young Hong S., Vijarnsorn P., Zhang G.-L., Arrouays D., Black H., Krasilnikov P., Sobocká J., Alegre J., Henriquez C.R., Mendonça-Santos M.L., Taboada M., Espinosa-Victoria D., Al-Shankiti A., Alavi-Panah S.K., Elsheikh E.A.E., Hempel J., Camps-Arbestain M., Nachtergaele F., Vargas R., 2015. World's soils are under threat. Soil 2: 1263-1272.

Novák T., Árendás T., Świtoniak M., 2018. Soils of an undulating, cultivated loess plateau in North Mezőföld, Central Hungary. [In:] Soil sequences atlas IV. [Eds.] Świtoniak M., Charzyński P., Machina Druku, Toruń: 113-122.

Olszewski Z., Barański E., Skłodowski P., 1965. Czarnoziemy Proszowskie. Roczniki Nauk Rolniczych 90-A-1: 61-106.

Paluszek J., 1995. Zmiany struktury i właściwości fizycznych czarnoziemów pod wpływem erozji wodnej Roczniki Gleboznawcze - Soil Science Annual 46(1/2): 21-35.

Paluszek J., 2013. Assessment of soil structure of Luvisols developed from loess classified in various complexes of agricultural suitability. Soil Science Annual 64 (2): 41-48.

Phillips J.D., Slattery M., Gares P.A., 1999. Truncation and accretion of soil profiles on coastal plain croplands: implications for sediment redistribution. Geomorphology 28: 119140.

Podlasiński M., 2013. Denudation of anthropogenic impact on the diversity of soil cover and its spatial structure in the agricultural landscape of moraine, West Pomeranian University of Technology, Szczecin (in Polish with English summary).

Soil Survey Staff, 2014. Keys to Soil Taxonomy, 12th ed. USDA, Natural Resources Conservation Service, Washington, DC: $633 \mathrm{pp}$.

Systematyka gleb Polski, 1989. Roczniki Gleboznawcze - Soil Science Annual 40(3/4): 1-150.

Systematyka gleb Polski, 2011. Roczniki Gleboznawcze - Soil Science Annual 62(3): 1-193.

Systematyka gleb Polski, 2019. Wydawnictwo Uniwersytetu Przyrodniczego we Wrocławiu, Polskie Towarzystwo Gleboznawcze, Wrocław-Warszawa: 292 pp. 
Świtoniak M., Dąbrowski M., Łyszkiewicz A., 2015. The influence of human-induced erosion on the soil organic carbon stock in vineyards of Fordon valley. Polish Journal of Soil Science 48(2): 197-211.

Świtoniak M., Mroczek P., Bednarek R., 2016. Luvisols or Cambisols? Micromorphological study of soil truncation in young morainic landscapes - Case study: Brodnica and Chełmno Lake Districts (North Poland). Catena 137: 583-595.

Valde-Nowak P., 2004. Neolit. Lessowe centra i górskie peryferie. [In:] (D. Abłamowicz Ed.) Zmiany środowiska geograficznego w dobie gospodarki rolno-hodowlanej. Studia $z$ obszaru Polski. Katowice: 383-394.

Walczowski A., 1982. Mapa geologiczna szczegółowa Polski w skali 1:50,000, arkusz Kazimierza Wielka (948). Wydawnictwo Geologiczne, Warszawa.

Walczowski A., 1984. Objaśnienia do Szczegółowej Mapy Geologicznej Polski, arkusz Kazimierza Wielka (948) w skali 1:50,000. Wydawnictwo Geologiczne, Warszawa.
Wasak K., Drewnik M., 2015. Land use effects on soil organic carbon sequestration in calcareous Leptosols in former pastureland - a case study from the Tatra Mountains (Poland). Solid Earth 6: 1103-1115.

Wiesmeier M., Lungu M., Huebner R., Cerbari V., 2015. Remediation of degraded arable steppe soils in Moldova using vetch as green manure. Solid Earth 6: 609-620.

Žižzala D., Juřicová A., Zádorová T., Zelenková K., Minařík R., 2019. Mapping soil degradation using remote sensing data and ancillary data: South-East Moravia, Czech Republic. European Journal of Remote Sensing 52, S1: 108-122.

Żyła M., 2007. Ewolucja gleb erodowanych w obszarach lessowych. Ph.D thesis. Jagiellonian University, Institute of Geography and Spatial Management: $145 \mathrm{pp}$.

Żyła M., 2009. Water and air properties of eroded loess soils of the Proszowice Plateau. Folia Geographica, ser. GeographicaPhysica 40: 91-103.

Received: August 4, 2019

Accepted: October 17, 2019

Associated editor: C. Kabata

\section{Wlaściwości i klasyfikacja silnie zerodowanych gleb po-czarnoziemnych występujących na Płaskowyżu Proszowickim (południowa Polska)}

Streszczenie: Badaniami objęto silnie zerodowane gleby występujące wśród czarnoziemów w wyżynnym krajobrazie Płaskowyżu Proszowickiego (południowa część Polski). Przeanalizowano ich morfologię i właściwości oraz przedyskutowano zagadnienie ich przynależności taksonomicznej. Biorąc pod uwagę kontekst krajobrazowy należy przyjąć, że gleby te powstały wskutek bardzo silnego zerodowania (ogłowienia) pierwotnie występujących w tych miejscach czarnoziemów. Te po-czarnoziemne gleby mają prostą budowę profilu glebowego, są względnie młode i można w nich udokumentować jedynie rozwój poziomu próchniczego, chociaż akumulacja próchnicy jest hamowana przez stale intensywne procesy erozyjne. Zarówno w badaniach makroskopowych, jak i mikroskopowych nie stwierdzono dowodów na występowanie procesu płowienia i brunatnienia. Gleby te są często klasyfikowane jako gleby słabo rozwinięte mimo tego, że charakteryzują się potencjalnie wysoką urodzajnością, co wynika zarówno z właściwości ich materiału macierzystego (uziarnienie, porowatość), jak i z ich wieku (zawartość węglanów w częściach ziemistych i w nodulach, alkaliczny odczyn w całym profilu). Z tego powodu nazwa "pararędzina" zaproponowana w Systematyce Gleb Polski, wydanie 6. wydaje się uzasadniona. Gleby te są klasyfikowane jako Entisols według USDA Soil Taksonomy oraz Regosols zgodnie z WRB.

Słowa kluczowe: czarnoziemy, Mollisols, regosole, Entisols, pararędziny, erozja gleby, klasyfikacja gleb 